\title{
Study of fishers' socioeconomic and cultural profile around the Loktak lake of Manipur, India
}

\author{
Nongmaithem Bijaya Lakshmi Devi ${ }^{1}$, Ajit Kumar Ngangbam ${ }^{2}$, \\ Dr. Sheela Immanuel ${ }^{3}$, and Ananthan P. $\mathrm{S}^{4}$ \\ ${ }^{I}$ Central Institute of Fisheries Education(CIFE) Fisheries Economics Extension and statistics Division, P.O. \\ Box400061, Mumbai, India \\ ${ }^{2}$ EUMAINE, Ghent university, Belgium, \\ ${ }^{3}$ Principle Scientist, Central Institute of Fisheries Education, P.O-061, Mumbai, India. \\ ${ }^{4}$ Scientist (Sr scale), Central Institute of Fisheries Education, P.O-061, Mumbai, India.
}

\begin{abstract}
Fishing is an ethnic occupation of the inhabitants around the Loktak lake of Manipur. Study of fishers' socioeconomic and cultural profile around the Loktak lake of Manipur was carried out in five villages around the Loktak lake of Manipur which were selected by adopting a case study cum survey method. The study revealed that 44 percent of the fishermen belonged to the old age, 58.67 percent had family size of more than 5 members, 88 percent had medium level of scientific orientation, 36 percent had annual income between Rs 20001-30000, 38.67 percent had 11-20 years of fishing experience, 34 percent of the fishers had middle school and 34 percent had high school level of education. Gender disparities and early marriage system were not found. Fishers were also found to have rich traditional knowledge regarding fishing. Religious institutes dominate the social structure and the fishers had given most important consideration on respect for old age among all other social values. The fishers spent highest annual expenditure i.e 30.96 percent for fishing activities. About 46 percent of the fishers were found to have credit amount of less than Rs. 5000 where poor fishermen act as borrowers and relatively well off fishermen as lenders.
\end{abstract}

Keywords: socioeconomic, Loktak lake, Manipur, fishers, ethnic.

\section{Introduction}

India is the second largest producer of freshwater fish in the world (2009). In this scenario, the Inland water bodies plays an important role. Inland fisheries provides a valuable source of protein-rich food and employment along with nutritional security and income to millions of the rural households. In 2008, the estimated inland capture fisheries production was 10 million tonnes which consist of fish and crustaceans (FAO, 2010). It forms the major source of livelihood and food for many rural poor of the landlock region where there is no coastal water bodies.

In 2002, there were 38 million commercial and subsistence fishermen and fish farmers all over the world. Of this total, 74 percent are engaged in capture fisheries and 26 percent in aquaculture. The world total fishery production of 133 million tonnes equated to an average productivity of 3.5 tonnes per person. By 2006 the number of world fishers increased to 43.5 million and the total fishery production were 143.6 million tonnes with an average productivity of 3.3 tonnes per person (FAO, 2011). According to 2001 census total population of the people in India is 1,027,015,247of which 5959144 people are fishermen and of this total, fishermen population of Manipur is around 32350 engaging in Inland Fisheries.

Fish is not only an important source of protein in Manipur but it serves an important part in the local cuisine in any social functions and ceremony. Fish production in the state for the year 2009-2010 was estimated at about 19200 tonnes (Department of Fisheries Manipur, 2009-2010). Of this total production, the fisheries of the Loktak lake contributes about 60 percent of the total production of the state. As Loktak lake being the largest wetland in the North-Eastern region of India,it has been referred to as the lifeline of the people of Manipur because of its importance in the socioeconomic and cultural life of the state.

The fishing village plays a significant role in the social and economic life of the fishermen of Manipur State. Fishing provides one of the primary sources of livelihood to the fishermen and it forms the major source of the cheap protein to the majority of the Manipur population. The most important factor for the development of the fishing industry is the upliftment of the livelihood and socioeconomic conditions of the fishermen who are in most backward conditions in our country where the population pressure surpasses the food production.

Inspite of the various development programmes taken up for the welfare of the ecosystem of the Loktak lake also, the ultimate developments of the socioeconomic conditions of the fisherfolk of the Loktak lake are poor. Therefore, taking into consideration of the importance of the fisheries of Loktak lake in the state and its role in the socioeconomic and cultural life of the fishermen, the present study was attempted with the following objectives. 


\section{Objectives:}

1) To study the social profile of the fishing communities in Loktak lake region.

2) To study the cultural profile of the fishing communities in Loktak lake region.

3) To study the economic and livelihood status of the fishing communities in Loktak lake region.

4) To find out the different relations exist between the variables of the fishers.

\subsection{Site description}

\section{Materials and methods}

Manipur is an Inland territory of Indian Union which is having a geographical area of $22,327 \mathrm{~km}^{2}$ located on the North-eastern border between India and Myanmar. Loktak lake is situated $38 \mathrm{~km}$ south of Imphal city, the capital of Manipur state. The Loktak lake is also known as the only Floating lake in the world due to the floating heterogeneous mass of vegetation, soil, and organic matters at various stages of decomposition called as Phumdi on it

The total population of the 55 rural and urban hamlets around the Loktak lake in 2001 was 279,935, accounting for 12 percent of Manipur's total population (Anjulika, 2010).

\subsection{Selection of villages}

The villages around the Loktak lake are mainly covered by two districts out of the nine districts of Manipur. Hence the district namely Bishnupur district and Imphal West district have selected for the study.

There are 36 villages around the Loktak lake of Manipur in which most of them were having fishing as their main occupation. Of these 36 villages, the five villages namely Moirang, Thanga, Keibul Lamjao, Ningthoukhong (Bishnupur District) and Mayang Imphal (Imphal west District) were selected for the study as they have large number of fishermen involving in fishing activities.

\subsection{Selection of the Respondents}

30 respondents from each village such that total 150 respondents were selected from 5 selected villages around the Loktak lake of Manipur for the study through random sampling technique where all the respondents were consisted of male population. For case study method 2 key informants were selected from each village such that total 10 respondents were selected for the study.

\subsection{Tools for Data Collection}

The datas were collected from the fishermen only by taking personal interview with the help of interview schedules incorporating all the items for which the informations were required. This method was used for the purpose of primary data collection. Data from the fishermen were collected in local language. The secondary data were collected from the published document of the State Fisheries Department and Loktak Development Authority.

\subsection{Statistical Tools Used}

To draw meaningful conclusion, relevant statistical tool like MS- Excel was used to perform Percentage analysis, mean and standard deviation, simple correlation coefficient and Rank Based Quotient.

\section{Rank based quotient (RBQ)}

Rank Based Quotient (RBQ) was used to quantify the data collected by preferential ranking technique by first ranking the parameters and then calculating the Rank Based Quotient (RBQ) given by Sabarathnam (1988), which is as follows:

$$
\text { R.B.Q. }=\frac{\sum \mathrm{fi}(\mathrm{n}+1-\mathrm{i})}{\mathrm{N} \times \mathrm{n}} \mathrm{X} 100
$$

Where in,

$\mathrm{fi}=$ Number of fishers reporting a particular problem under $\mathrm{i}^{\text {th }}$ rank

$\mathrm{N}=$ number of fishers

$\mathrm{n}=$ number of problems identified

\subsection{Social Profile Characteristics of the Fishers}

\section{Results and discussion}

Data on Table-1 revealed that majority (44\%) of the fishermen belonged to the old age of more than 46 years. This may be due to the reason that most of the children below the age of 20 years were mostly pursuing their 
education. Majority (58.67\%) of the fishers had family size of more than five members. It was observed that majority (91.33\%) of the fishers were Hindus and only 8.67 percent were Muslims. Among the five villages that were selected around the Loktak lake, only one village has some Muslim population and the rest were all Hindu inhabited areas. About 34 percent of the fishers had middle school level of education and 34 percent of the fishers had high school level of education. All the respondents selected were constituted with male population. Male and female are treated equally in terms of their rights they are enjoying and there is no gender discrimination in these areas. They shared their roles and responsibility equally for running their household and livelihood activities.

From Table 2 it was safely noted that majority $(96.6 \%)$ of the respondents were found living in Kuccha house and hundred percent of the fishers had their own house. It was found out that 54 percent of the respondents had small house and 80 percent used electricity as the source of light. This may be due to the fact that electricity connection is difficult to take into those small floating huts in the middle of the lake. All (100\%) the fishers used firewood as cooking fuel.

Majority $(82 \%)$ of the fishers were found not attended any training programmes (Table 3 ). As per the suggestions given by the people, it was reported that they want to get training programmes in fish canning technology and new fishing methods.

Table-4 revealed that 20 percent of the respondents got information from fisheries department once in a year, 20 percent monthly and 20 percent once in three months. This may be due to the fact that majority of the respondents were having fishing as their main occupation and hence they had more contact with the fisheries department.

Majority $(53.33 \%)$ of the respondents had social participation as non-members of gram Panchayat (table- 5) as the fishermen were found to involve in full time fishing and they are engaged throughout the day and hence they would not have found enough time to participate in the Panchayat activities by taking responsibilities in the Panchayat.

It was observed from table 6 that 68 percent of the fishers possessed mobile phones followed by 34 percent possessed radios and 5 percent possessed televisions. None of the respondent had possessed VCR/VCP and computer. Majority (84\%) of the fishers had never utilized mass media followed by 11.33 percent had occasional mass media utilization and 4 percent had regular mass media utilization. Majority (88\%) had medium level of scientific orientation which may be due to their education followed by 6.6 percent high level and 5.3 percent low level of scientific orientation. This may be due to the fact that very small percentage of the people participated in the scientific meetings and also they had low social participation.

The data in Table-7 revealed that nearly 40 percent of the fishers had ration card with yellow colour which indicated Antyodaya Anna Yojana (AAY) and another 40 percent of the fishers had green ration card i.e. below poverty line (BPL) followed by 20 percent Pink Ration card holder. About 40 percent of the fishers purchased rice from ration shop and another 40 percent of the fishers purchased kerosene and 20 percent of the fishers purchased both rice and kerosene from the ration shop.

Majority $(94.67 \%)$ of the fishers took their children for pulse polio immunisation camp in nearby Primary Health Centre and 5.3 percent of the fishers did not go. This may be due to the fact that some of the respondents were staying on floating huts in the middle of the lake where entry of vehicle is not possible rather than boat.

The frequency of distribution of the public distribution system in these study area were reported to be very low i.e. once in five months. Rice and kerosene were the main commodity that the people were buying from the ration shop. The commodities available in the ration shop were somewhat i.e. 10 percent cheaper than that of the market. From Table-8, it was observed that social changes was observed in family set up, marriage pattern, economic relation, institutions, beliefs and social relationship. Family set up was found changing from joint to nuclear type and the knowledge of family planning has diffused in this generation. Marriage ceremony was found changing from traditional to modern type. It was observed in Table-9, that women were participating in many of the decision making activities on par with men. It is clear that decision making has a direct relation with the work they are doing.

According to the ranks given by RBQ in table 10, it was observed that religious institutions dominate the social structure followed by Panchayat and Political organisation. This showed that majority of the fishers had given due importance to religion and they are strong believers too.

\subsection{Cultural Profile Characteristics of the Fishers}

Traditional knowledge refers to the traditions and practices of certain regions or communities that encompasses the knowledge, wisdom and teachings of these communities. Fishers also had traditional knowledge and belief regarding fishing activities. They used the directions of winds to predict the fish accumulation. They used Hydrilla sp. for catching Osteobrama belangiri. In summer season, the fishes are 
available mostly in the water bodies where macrophytes are not grown whereas in winter the fishes are available in macrophytes growing areas.

Sizes of the gill nets used were different with seasons. They also used different traditional feeds as attractants to catch the fish. The fishers also had strong believed that while doing phum namba (which means arranging the phum with feeds and gill nets) for catching the fish, if strong wind comes then some evil is coming. Further they used colour and temperature of the water to predict the fish catch.

All the respondents had Manipuri language as their mother tongue. About 43.33 percent of the fishers went monthly to the place of worship. About 86 percent of the fishers had prayers 2 times a day. It was observed that majority $(46.67 \%)$ of the fishers had maintained the age limit for marriage at more than 25 years (Table 11). The festivals celebrated by the fishers are Diwali, Holi, Idul zuha, Phaoibee leisang haraoba (local deities) which are celebrated in winter whereas in summer the local deities such as Thanga-ching ninghou, Sendra ningthou, Umang lei haraoba, Ibudhou thangjing and Umang lei mayang Imphal and other festivals like Durga puja, Ratha jatra and Idul fitri are celebrated.

It was observed from Table-12 that according to the rank order resulted by using RBQ techniques, it was found out that the fishers had given most important consideration on respect for old age where old aged people are given more recognitions and respect.

\subsection{Economic and Livelihood Profile Characteristics of the Fishers}

Table -13 revealed that all the respondents were having fishing as the primary occupation. Under secondary occupation, only 3.3 percent had net making and 0.66 percent had trap making. No occupational shifts were observed for the fishers around the Loktak lake region. Majority (36\%) of the fishers had annual income between Rs 20,001-30,000. About 38.67 percent of the fishers had 11-20 years of experience. About 39.33 percent of the fishers had poultry. About 57.33 percent of the fishers were found to have land of 151-250 Sq. ft. It was observed that majority $(68.67 \%)$ of the respondents worked 3 hours/day. All the respondents were found to work 25 to 28 days in a month and work 9-12 months in a year. About 44.67 percent of the fishers spent their leisure time on net or cage repairing. An average yearly expenditure of about 30.96 percent goes for fishing activities (table 14). Nearly 46 percent of the fishers were having credit amount of less than 5000 Rs (table 15).

From table 15, it was noted that gill net no. 45 was owned by 54.67 percent of the fishers as more number of fishes were trapped in the mesh size of $45 \mathrm{~mm}$. Craft mainly consisted of dugout canoes with different sizes. Accordingly 30 percent of the fishers had dugout canoes of $18 \mathrm{ft}$. long and 17inches width as large size dugout canoes are comparatively expensive, so only few people could afford it. Dugout canoes with single log or double log were mainly operated in Loktak lake. These canoes were mainly constructed from local wood Uningthou. Dugout canoes with single log were found to be costlier than double logs.

Table 17 revealed that 57.33 percent of the fishers were found to have land of 151-250 Sq. ft. followed by 24 percent with 251-350 Sq. ft. and 9.33 percent with 351-450 Sq. ft.

\subsection{Interrelationship Between the Profile Characteristics of the Fishermen}

From the inter matrix table (Table 18), it was found out that different relations exist between the variables of the fishers. It was found out that age of the fishers were directly related to income, family type and experience. This may be due to the fact that with the increase in age they gain more experience in fishing and the family tends to be more expanded due to which the size of the family becomes bigger and the earning members were more. Education of the fishers were directly related to mass media utilisation, scientific orientation and social participation. This may be due to the fact that most of the educated fishers belonged to young age group. Income of the fishers were directly related to earning members, family type, family size, communication asset possessed and scientific orientation. This may be due to the fact that with the increase in the family size, earning member increases which leads to increases in income in each household. Family type of the fishers were directly related to family size, communication asset possessed and experience and negatively related to social participation. With the increase in family type or size, income increases due to which more communication assets were possessed by them. Family size of the fishers were directly related to scientific orientation. Communication asset possessed of the fishers were negatively related to mass media utilization, scientific orientation and social participation. This may be due to the fact that farmers they usually get less leisure time therefore even though they possess they found less time to utilize it. Mass media utilization of the fishers were directly related to scientific orientation and social participation. There were no significant relationship exist between the social participation with other variables of the fishers.

\section{Implications}

A proper extension linkage mechanism like interactive meetings should be organised between the extension personnel's of the State Fisheries department and the fishers for effective transfer of technologies. 
Women should be made to form SHG to increase their income earning. Government should provide financial support in procurement of gears and crafts where the fishers spent majority of their expenditure. Training programmes should be arranged frequently and should ensure that a maximum number of fishers should participate at the village level.

\section{Acknowledgement}

The authors would like to thank Central Institute of Fisheries Education (CIFE), Mumbai for sponsoring this work. We also thank Dr. Sheela Immanuel for providing necessary guidance at every steps of this research work.

\section{Reference}

[1] Anjulika, T. 2010. There is nothing you didn't get from Loktak. Infochange News \& Features, available at http://infochangeindia.org/environment/loktak-a-dying-lake/from-owners-to-occupiers.html.

[2] FAO, 2010. World review of fisheries and aquaculture. In: The state of world fisheries and aquaculture 2009. FAO, Rome, pp. 3-87.

[3] FAO, 2011. Fishing people. In: FAO,fisheries and aquaculture department available at http://www.fao.org/fishery/topic/13827/en.

[4] Sabarathanam, V. E., 1988. Manuals of Field Experience Training for ARS Scientists. Hyderabad:NAARM.

Table 1. Personal profile characteristics of the fishers

\begin{tabular}{llll} 
& & & $\mathbf{n}=\mathbf{1 5 0}$ \\
\hline Characteristics & Category & No. & Percentage (\%) \\
& & \\
& & \\
\hline Age (years) & Upto 25 years & 2 & 1.33 \\
& $26-35$ & 25 & 16.66 \\
& $36-45$ & 57 & 38 \\
Family type & 46-above & 66 & 44 \\
& Nuclear & 133 & 88.66 \\
Family size & Joint & 17 & 11.33 \\
& $<5$ members & 62 & 41.33 \\
Caste & $>5$ members & 88 & 58.67 \\
& SC & 30 & 20 \\
& OBC & 99 & 66 \\
Religion & Minority & 13 & 8.6 \\
& General & 8 & 5.3 \\
Education & Hindu & 137 & 91.33 \\
& Muslim & 13 & 8.67 \\
& Illiterate & 12 & 8 \\
& Primary & 27 & 18 \\
& Middle & 51 & 34 \\
& High & 51 & 34 \\
& Higher secondary & 5 & 3.3 \\
& Collegiate & 4 & 2.6 \\
\hline
\end{tabular}

Table 2. House and Habitation

$n=150$

\begin{tabular}{llll}
\hline Characteristics & Category & No. & Percentage (\%) \\
\hline $\begin{array}{l}\text { House and Habitation } \\
\text { a) Type of houses }\end{array}$ & Kuccha & 145 & 96.6 \\
& Pucca & 0 & 0 \\
& Semi pucca & 5 & 3.3 \\
& & & 100 \\
b) Ownership status & Owned & 150 & Nil \\
& Rented & 0 & Nil \\
& Leased & 0 & 6 \\
c) Area of the house (in Sq. ft) & Very small houses & 9 & 54 \\
& Small houses & 81 & 28.67 \\
& Medium houses & 43 & 11.33 \\
d) Sanitation & Large houses & 17 & 96.67 \\
\hline
\end{tabular}




\begin{tabular}{llll} 
& Pucca Latrine & 5 & 3.3 \\
e) Drinking water & Lake & 105 & 70 \\
& Own pond & 15 & 10 \\
f) Lighting & Public pond & 30 & 20 \\
& Electricity & 120 & 80 \\
& Solar & 30 & 20 \\
\hline
\end{tabular}

Table 3. Training programmes attended

\begin{tabular}{|c|c|c|c|}
\hline & & $\mathbf{n}=1$ & \\
\hline Characteristics & $\begin{array}{l}\text { Category } \\
\text { (No. of trainings) }\end{array}$ & No. & Percentage (\%) \\
\hline $\begin{array}{ll}\text { Training } & \text { programmes } \\
\text { attended } & \\
\end{array}$ & $\begin{array}{l}1 \\
2 \\
\text { Not attended }\end{array}$ & $\begin{array}{l}25 \\
2 \\
123\end{array}$ & $\begin{array}{l}16.67 \\
1.33 \\
82\end{array}$ \\
\hline
\end{tabular}

Table 4. Extension agency contact

\begin{tabular}{|c|c|c|c|c|c|c|c|c|c|}
\hline \multirow[t]{2}{*}{$\begin{array}{l}\text { Charactei- } \\
\text { stics }\end{array}$} & \multirow[t]{2}{*}{ Category } & \multirow{2}{*}{$\begin{array}{l}\text { Once } \\
\text { year } \\
\text { No. } \\
\end{array}$} & \multirow{2}{*}{$\begin{array}{l}\text { in } a \\
(\%) \\
\end{array}$} & \multicolumn{2}{|c|}{ Monthly } & \multicolumn{2}{|c|}{$\begin{array}{l}\text { Once in six } \\
\text { months }\end{array}$} & \multirow{2}{*}{$\begin{array}{l}\text { Once in } \\
\text { months } \\
\text { No. }\end{array}$} & \multirow{2}{*}{$\begin{array}{l}\text { three } \\
(\%) \\
\end{array}$} \\
\hline & & & & No. & $(\%)$ & No. & $(\%)$ & & \\
\hline \multirow{4}{*}{$\begin{array}{l}\text { Extension } \\
\text { agency } \\
\text { contact }\end{array}$} & Source: & & & & & & & & \\
\hline & $\begin{array}{l}\text { 1. Fishery } \\
\text { Dept. }\end{array}$ & 30 & 20 & 30 & 20 & Nil & 0 & 30 & 20 \\
\hline & $\begin{array}{ll}\text { 2. } & \text { Forest } \\
\text { Dept. } & \end{array}$ & 30 & 20 & Nil & 0 & Nil & 0 & Nil & 0 \\
\hline & 3. FFDA & 30 & 20 & nil & 0 & nil & 0 & nil & 0 \\
\hline
\end{tabular}

Table 5. Social participation

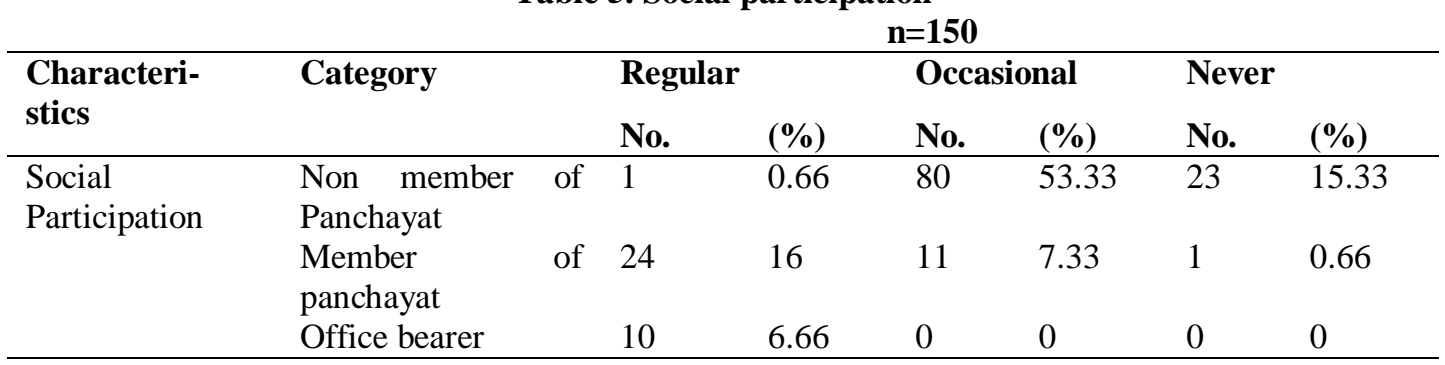

Table 6. Communication assets, mass media utilisation and scientific orientation

\begin{tabular}{|c|c|c|c|c|}
\hline & & \multicolumn{3}{|c|}{$n=150$} \\
\hline Characteristics & & Category & No. & Percentage (\%) \\
\hline \multirow{3}{*}{$\begin{array}{l}\text { Communication } \\
\text { possessed }\end{array}$} & asset & Radio & 51 & 34 \\
\hline & & Television & 5 & 3 \\
\hline & & Phone & 102 & 68 \\
\hline \multirow{3}{*}{\multicolumn{2}{|c|}{ Mass media utilisation }} & Regular & 6 & 4 \\
\hline & & Occasioanal & 17 & 11.33 \\
\hline & & Never & 126 & 84 \\
\hline \multirow{3}{*}{\multicolumn{2}{|c|}{ Scientific orientation }} & Low & 8 & 5.3 \\
\hline & & Medium & 132 & 88 \\
\hline & & High & 10 & 6.6 \\
\hline
\end{tabular}


Table 7. Access to basic public service

\begin{tabular}{llll}
\hline Characteristics & Category & No. & Percentage (\%) \\
& & & \\
& & & \\
\hline Access to basic public service & & 60 & 40 \\
a) Ration card & Yellow & 30 & 20 \\
& Red & 60 & 40 \\
b) Purchase from ration shop & Green & 60 & 40 \\
& Rice & 60 & 40 \\
& Kerosene & 30 & 20 \\
c) PHC & Rice and kerosene & 142 & 94.67 \\
& Pulse polio immunisation & 8 & 5.3 \\
\hline
\end{tabular}

Table 8. Social process

\begin{tabular}{ll}
\hline Social process & Degree of change \\
\hline Family set up & $* *$ \\
Marriage & $* *$ \\
Customs & $*$ \\
Social techniques & $*$ \\
Economic relations & $* *$ \\
Institutions & $* *$ \\
Beliefs & $* *$ \\
Social relationship & $* *$ \\
\hline indicates no change & $* *$ indicates change
\end{tabular}

Table 9. Gender in decision making

\begin{tabular}{llll} 
& \multicolumn{1}{c}{$(\mathbf{n = 1 5 0 )}$} & \\
\hline Activities & Initiates & Decides & Implements \\
\hline Money management & women & both & women \\
Children's education & women & both & men \\
Marriage & women & both & women \\
Health & men & men & both \\
& men & men & men \\
Social actions & men & men & men \\
Fishing & women & women & women \\
Fish selling & women & women & women \\
House management & & &
\end{tabular}

Table 10. Frequency distribution of RBQ values given by farmers for social organisation

\begin{tabular}{lll} 
& \multicolumn{1}{c}{$(\mathbf{n = 1 5 0})$} & \\
\hline Social organisation & RBQ & Rank \\
\hline Religious organisation & 79.38 & I \\
Panchayats & 79.11 & II \\
Political organisations & 67.72 & III \\
Voluntay organisation & 60.12 & IV \\
Local bodies & 52.71 & V \\
\hline
\end{tabular}


Table 11. Religion or rituals and age of marriage

\begin{tabular}{llcc}
\hline Characteristics & Category & No. & Percentage (\%) \\
\hline Religion or rituals & Monthly & 65 & 43.33 \\
a) Frequency of going to the place & Once in every & 30 & 20 \\
& newmoon & & \\
& Yearly & 55 & 36.67 \\
& Twice & 129 & 86 \\
b) Frequency of prayer/ Puja & Thrice & 8 & 5.33 \\
& Five & 13 & 8.6 \\
& 18 & 2 & 1.33 \\
& $18-19$ & 9 & 6 \\
Age of marriage(years) & $20-21$ & 19 & 12.67 \\
& $22-23$ & 12 & 8 \\
& $24-25$ & 38 & 25 \\
& $>25$ & 70 & 46.67 \\
\hline
\end{tabular}

Table 12. Frequency distribution of RBQ values given by farmers for social values $(\mathbf{n}=150)$

\begin{tabular}{lcc}
\hline & RBQ & Rank \\
\hline Social values & 80.56 & I \\
Respect for old age & 70.70 & II \\
Famigious attitude & 63.01 & III \\
Charity & 59.13 & IV \\
Conflict resolution pattern & 50 & V \\
Killing of animals & 42.76 & VI \\
\hline
\end{tabular}

Table 13. Economic profile characteristics of the fishers

\begin{tabular}{clcc} 
& & $\mathbf{n = 1 5 0}$ & \\
\hline Characteristics & Category & No. & Percentage (\%) \\
\hline Primary occupation & Fishing & 150 & 100 \\
Secondary occupation & Net making & 5 & 3.3 \\
& Trap making & 1 & 0.66 \\
& Upto 10000 & 37 & 24.67 \\
& $10001-20000$ & 40 & 26.67 \\
Annual Income (in Rs.) & $20001-30000$ & 54 & 36 \\
& $30001-40000$ & 18 & 0.66 \\
Fishing experience & $40001-50000$ & 1 & 8 \\
(in Years) & $1-10$ & 12 & 38.67 \\
& $11-20$ & 58 & 24.67 \\
Livestock & $21-30$ & 37 & 24.67 \\
\end{tabular}

Table 14. Average yearly expenditure

\begin{tabular}{clc} 
& \multicolumn{2}{c}{$\mathbf{n = 1 5 0}$} \\
\hline Characteristics & Category & Average Percentage (\%) \\
\hline & Food & 22.28 \\
& Clothing & 10.16 \\
Average yearly & Housing & 10.03 \\
expenditure(Rs) & Health & 13.63 \\
& Education & 12.88 \\
& Entertainment & 0.7 \\
& Fishing activities & 30.96 \\
\hline
\end{tabular}


Table 15. Credit orientation

\begin{tabular}{clcc} 
& \multicolumn{3}{c}{$\mathbf{n = 1 5 0}$} \\
\hline Characteristics & Category & No. & Percentage (\%) \\
\hline \multirow{5}{*}{ Credit amount (in Rs.) } & Nil & 44 & 29.33 \\
& $<5000$ & 69 & 46 \\
& $5001-10000$ & 29 & 19.33 \\
& $10001-15000$ & 1 & 0.66 \\
& $>15000$ & 7 & 4.67 \\
\hline \multirow{5}{*}{ Interest rate } & $5 \%$ & 100 & 66.67 \\
& $4 \%$ & 2 & 1.33 \\
& $3.50 \%$ & 1 & 0.67 \\
& $2 \%$ & 1 & 0.67 \\
& $3 \%$ & 2 & 1.33 \\
\hline
\end{tabular}

Table 16. Gear and craft ownership

\begin{tabular}{llcc} 
& & \multicolumn{2}{c}{$\mathbf{n = 1 5 0}$} \\
\hline Characteristics & Category & No. & Percentage (\%) \\
\hline Gear ownership & Gill net no.45 & 82 & 54.67 \\
Craft ownership & $18 \mathrm{ft} .17$ inches & 45 & 30 \\
(Dugout canoes) & & & \\
(length \&width) & & & \\
\hline
\end{tabular}

Table 17. Physical asset

\begin{tabular}{llcc} 
& & n=150 & \\
\hline Characteristics & Category & No. & Percentage (\%) \\
\hline & 50-150 Sq. ft & 11 & 7.33 \\
Physical asset & 151-250 Sq. ft & 86 & 57.33 \\
Immovable asset & 251-350 Sq. ft & 36 & 24 \\
Land ownership(Sq. ft) & 351-450 Sq. ft & 14 & 9.33 \\
& $>450$ Sq. ft & 3 & 2 \\
\hline
\end{tabular}

Table 18. Interrelationship between the profile characteristics of the fishermen

\begin{tabular}{|c|c|c|c|c|c|c|c|c|c|c|c|c|}
\hline & $\mathrm{A}$ & B & C & D & $E$ & $F$ & G & $\mathrm{H}$ & I & $\mathrm{J}$ & $\mathrm{K}$ & $\mathrm{L}$ \\
\hline A & 1 & & & & & & & & & & & \\
\hline B & -0.09 & 1 & & & & & & & & & & \\
\hline $\mathrm{C}$ & $0.241^{* *}$ & 0.0108 & 1 & & & & & & & & & \\
\hline $\mathrm{D}$ & 0.048 & 0.033 & $0.478 * *$ & 1 & & & & & & & & \\
\hline E & $0.184 *$ & 0.009 & $0.265^{* *}$ & $0.183 *$ & 1 & & & & & & & \\
\hline F & 0.012 & 0.025 & $0.204^{* *}$ & $0.496 * *$ & $0.300 * *$ & 1 & & & & & & \\
\hline$G$ & -0.095 & 0.001 & $0.286 * *$ & 0.0908 & $0.172 *$ & $\overline{0} .0103$ & 1 & & & & & \\
\hline $\mathrm{H}$ & -0.055 & $0.217 * *$ & $-0.174 *$ & -0.128 & -0.022 & -0.036 & $0.218 * *$ & 1 & & & & \\
\hline I & 0.107 & $0.172 *$ & $0.154 *$ & $0.145 *$ & -0.019 & $0.156^{*}$ & $\overline{0} .334 * *$ & $0.363 * *$ & 1 & & & \\
\hline $\mathrm{J}$ & $0.779 * *$ & -0.073 & 0.061 & $-0.135 *$ & $0.152 *$ & -0.102 & -0.045 & -0.058 & 0.081 & 1 & & \\
\hline $\mathrm{K}$ & 0.044 & 0.112 & 0.062 & $0.202 * *$ & 0.023 & 0.1306 & 0.106 & 0.058 & 0.028 & -0.029 & 1 & \\
\hline L & -0.133 & $0.136 *$ & -0.129 & -0.129 & $-0.141 *$ & $-147^{*}$ & $-0.138 *$ & $0.232 * *$ & 0.096 & -0.069 & -0.052 & 1 \\
\hline
\end{tabular}

**- Significant at $1 \%$ level, * - Significant at $5 \%$ level

Where,

A - Age, B- Education, C- Income, D- Earning member, E- Family type, F- Family size, GCommunication Asset possessed, H- Mass media utilization, I- Scientific orientation, J- Experience in fishing, K- Credit orientation,

L- Social participation 